\title{
Truth-telling: a key to liberating Australia from a deliberate silence
}

\author{
Madeleine Wedesweiler
}

University of Technology Sydney, Faculty of Arts and Social Sciences, PO Box 123, Ultimo

NSW 2007, Australia.madeleine.wedesweiler@student.uts.edu.au

\begin{abstract}
There have been a number of recent calls for "truth-telling" about aspects of Australia's past. In order to deal with the horrors of our collective past they must be dredged up and confronted very widely, honestly and openly. In this regard there is much we can learn from similar processes overseas.
\end{abstract}

Key words: truth-telling; Makarrata process; Redfern Address; Uluru Statement from the Heart; Reconciliation;

The idea that historical truth-telling is the strongest or only path to national healing has gained traction in historical and cultural theory. In order to deal with the horrors of our collective past they must be dredged up and confronted very widely, honestly and openly. Sceptics argue that this is not enough and is not actually justice; simply knowing about the truth of what has been inflicted upon Indigenous people is not enough to compensate them and does not go far enough to heal communities and their wounds, because it is not the same as doing something. However, it is a vital first step. Public education can lead to public support which can lead to policy change, as was arguably the case in the 1967 Referendum. In his Quarterly Essay Mark McKenna theorises that 'telling the truth will liberate us', potentially enough to achieve:

a meaningful constitutional settlement with Indigenous Australians, to become a republic, and perhaps in the process, to redefine the way we see ourselves and the way the country is seen by others (McKenna 2018, p. 16).

In this essay, I will consider the process for truth-telling on which Australia has partially begun to head. I say partially because there are truths that are told through the education 
system, historians' work and the media, but there is still in many ways a deliberate silence and a misunderstanding about Australia's Aboriginal history. Atrocities of the past have not been confronted, suffering has not been heard, apologies and peace have not been offered. I will examine the work of the Bringing Them Home Inquiry, the Massacre Map project, and the call in the Uluru Statement from the Heart. Looking overseas to (imperfect) examples that Australia could take, I will compare the way the terrible public history of the Holocaust is and has been communicated through a truth-telling process in Germany and the concept of guilt and responsibility that haunts the public and official record.

The Uluru Statement from the Heart asks for 'a Makarrata Commission to supervise a process of agreement-making between governments and First Nations and truth-telling about our history'. The claim is simple; neither grandiose, nor particularly bold nor unachievable. Yet it was rejected by the Turnbull government with very little explanation, so that we are forced to speculate as to why. Some Australians don't want to undergo a truth-telling process on behalf of themselves or their nation. Researcher and international development consultant Louise Vella said:

The classic argument against truth and reconciliation processes is that it is 'opening a can of worms'. The analogy of 'healing a wound' is often used - that you need to clean it up so it can heal properly. (Daley 2018)

While many are ambivalent or ignorant to the idea of a truth-telling process, some are actively against it for a number of complex reasons. Part of the reason that the Turnbull government rejected the Uluru Statement from the Heart and its truth-telling clause was Turnbull's weak position as a leader and unwillingness to take a risk within his party. But another reason is the likelihood that the voting public would also reject the sentiments. As Galarrwuy Yunupingu describes, the rejection of the Uluru Statement from the Heart reflects a deeper cultural prejudice. 'The Australian people know their success is built on the taking of the land, in making the country their own,' he argues, 'which they did at the expense of so many languages and ceremonies and songlines - and people - now destroyed. They worry about what has been done for them and on their behalf, and they know that reconciliation requires much more than just words' (The Monthly 2016). Mick Dodson agrees, claiming that there's 'something in the Australian psyche that goes back to colonisation and the way in which present-day Australia came by the country and there's fear of facing up to that truth...We don't want to confront these wrongs and be called to account for them'. Dodson suggests that there is an Australian state of heart and mind that was inherently resistant to confronting a historical truth: 'There was more than an accidental correspondence between the ruin of Aboriginal, and the making of European life in Australia. There was, in fact, a functional concomitance' (Saturday Paper 2017). A Makaratta process that leads to mass dispossession of non-Indigenous people is of course extreme and unlikely. And yet, the fear of this is identifiable and is a factor as to why the process has stalled.

Many have begun to speculate on what this kind of truth-telling commission would actually look like and aim to achieve. Paul Daley asks: 
Given that so many crimes against Indigenous people in Australia - such as shootings, massacres and poisonings, the theft of Indigenous land and deaths in custody - reverberate generationally to manifest in pervasive poverty, economic and social disadvantage, should any truth-telling process be punitive or restorative in its intent? Is it possible for it to be both? (Daley 2018)

Others have looked overseas to other examples of restorative truth-telling processes in South Africa, Rwanda and Northern Ireland. Using the German example of truth-telling, it is possible to see the Nuremberg trials as a truth-telling process which to some extent allowed Germans to go through a process of punitive justice and some semblance of retribution and find the potential to work towards a new society. This process is called 'Vergangenheitsbewältigung' which is explained by P. Rutschmann:

Vergangenheitsbewältigung as such expresses the manner in which Germans come to grips with or interpret their past and to what degree their interpretations of history reflect feelings of continued responsibility towards the survivors of the former victims ... does the act itself of continually working through the past contribute to a more gradual and subsequently healthier sense of national identity? (Rutschmann 2011)

This was, however, a process done through the criminal courts, with perpetrators who were still alive. In reference to an Australian process, Criminologist John Braithwaite points out that because the 'worst offenders' who committed historical violence against Indigenous Australian are 'mostly dead', the inclusion of truth-telling in punitive justice has limited relevance. Braithwaite also states that:

Part of what reparative justice is about is compensating for the impossibility of criminal justice ... perhaps institutional reform and prevention of future abuses is the bigger justice imperative - justice as a better future - rather than backward-looking punitive justice. (Daley 2018)

Because of the deeply emotional and personal nature of the past, any truth-telling process would be highly emotionally charged; it is not a neutral or normal conversation. Though there can be some room in a truth-telling process for guilt to be felt, guilt is not what will bring healing and can turn into defensiveness and aversion to participating in reconciliation. Many Australians including former prime minister John Howard resent the idea that they should feel guilt and take responsibility for injustices they have not committed. Paul Keating's Redfern Address touches on the idea of guilt and its uselessness as an emotion, where empathy and compassion would serve much better. Returning to the German example, the idea of guilt is often discussed because there are many people still living who were complicit with the Nazi regime. But ultimately there is not a need for younger generations to carry on this guilt because it is not conducive to progress or to bringing on board those who need to be brought on board. The truth is hard, the truth is painful and restorative justice requires listening and emotional intelligence and will not occur where there is defensiveness, aggression or reluctance. 
The reality of the history wars means that even when historians are telling the truth they can be forced to be conservative. The massacre maps are the result of thousands of hours of work and research and are a powerful resource. Reading the methodology used to make the maps reveals the cautious approach the authors took to avoid backlash:

This is a single number so that it can be used in calculations. Conservative estimates are used. For example, if records indicate 6 to 10 people were killed we use the figure 6 .

There are also so many incidents where under 6 people were killed that have not been included in the data. One can only hope that more research is supported that allows more work on the massacre maps to be undertaken particularly in Western Australia. One can also hope that those who need to be made aware of the extent of the deaths and who need to confront the reality of the Frontier Wars do so. The Massacre Maps in part counter the fact that we know so much about the ANZACS but not the actual Frontier Wars. There was some criticism on Twitter and online that the publishing and sharing of the Massacre Maps is simply allowing white people to perform empathy appear 'woke' and does not go towards improving outcomes for Indigenous people. I would argue otherwise, that truth-telling is part of a perhaps slower wider-reaching process to change the narrative around the history of Indigenous people and assume that that will eventually improve 'real life' outcomes. Truthtelling is about cutting through the silence and misinformation. As Bailey and Brawley write, 'despite a wealth of subsequent scholarship documenting the violence and dispossession that characterised European colonisation, considerable gaps in public awareness about these foundational events remain' (Bailey \& Brawley 2018).

One of the greatest truths that has not been told is in our Constitution. It does not tell the truth of Australia's Indigenous history and it does not communicate the heritage or the recognition or the existence of the world's oldest continuing population. Constitutional Recognition is undoubtedly connected to the idea of truth-telling, and although to some it is seen as a token gesture, I would argue that recognising Australia's Aboriginal heritage in the Constitution is (rightly) rewriting the foundational myths of our nation and is a significant legal discursive shift. Charles Taylor argues that not being seen is akin to a form of oppression.

The thesis is that our identity is partly shaped by recognition or its absence, often by the misrecognition of others, and so a person or group of people can suffer real damage, real distortion, if the people or society around them mirror back to them a confining or demeaning or contemptible picture of themselves. (Taylor 1997)

Taylor applies this theory to the idea of personal identity and constitutional recognition, though the crux of his argument can also be applied to the idea of history; if we are not truthful or open or acknowledging of it then we are harming and oppressing Aboriginal people. Narratives around the past do matter and have an impact on how people presently view Aboriginal people. 
To state what may be somewhat obvious, truth-telling is not a linear, simple process that ends in a clear resolution satisfying all parties. This was certainly true in regard to the Bringing Them Home inquiry into the Stolen Generations, which is considered in this essay as a truth telling exercise. It is also an example of the truth being told but to an audience not prepared to fully listen; in the sense that recommendations from the report have been ignored and a process for proper reparations to be given to Indigenous people removed from their families does not exist, 22 years later. Peter Read's analysis of the larger and smaller truths of the Stolen Generations provides a complex answer to the question, 'Can historians tell the truth about history?'. Read talks about facts that emerge that are contra to the greater narrative, but in the end add to, rather than undermine it (Read 2002). Read is one of many writers who understand that there is much nuance and many layers in historical truths. The truth of Australian history needs to be told but it also needs to be heard. It needs to be listened to. Non-Indigenous Australians should employ the techniques of deep listening or Dadirri, as explained by Miriam-Rose Ungunmerr who deserves to be quoted here in full:

It is perhaps the greatest gift we can give to our fellow Australians. In our language this quality is called dadirri. It is inner, deep listening and quiet, still awareness. Dadirri recognises the deep spring that is inside us. We call on it and it calls to us. This is the gift that Australia is thirsting for. It is something like what you call "contemplation". When I experience dadirri, I am made whole again. (Ungunmerr, p1. 2017)

How do we tell the truth, and how do we communicate it to the public on a mass-scale so that change can be affected? Truth-telling is incorporated into the school education system, in a curriculum that is flawed but can still be considered as progress compared to previous iterations and the Great Australian Silence, as defined by WEH Stanner (Stanner 1969). What is lost in the curriculum is often stories of resistance and stories of empowered Aboriginal people, in their own words, from their own perspectives, as agents of their own destiny rather than as passive people enslaved to the government. As Paul Daley writes 'much of truthtelling involves correcting the incorrect and racist records'. This is occasionally made easier by new technology and archiving; perhaps it will be easier in the future to trace and tell stories with Western technology:

Time's eroding sands have a way of exposing fact, if not necessarily truth. And so considerably more raw archival material that illuminates past lives and events is now available thanks to Trove and other digital repositories of early newspapers, colonial records and photographs, and Indigenous voices and art. (Daley 2018)

Daley's article and larger body of work highlights what is also lost in the truth-telling of Aboriginal history: the history of resistance and protest. The fact that sovereignty was never ceded and land, such as the Canberra region, was stolen in the face of resistance, is obscured by the larger truths of historical narratives.

Unfortunately, based on the evidence, it seems that Australia under a Liberal Government is not ready for a truth-telling process and potentially not ready for Constitutional Recognition. 
However, at the time of writing this essay it is unclear which direction newly-elected Prime Minister Scott Morrison will take on truth-telling, Constitutional Recognition and Aboriginal affairs more broadly. His support of Captain Cook monuments is troubling. How weak a comparison to Paul Keating, Malcolm Turnbull and Scott Morrison make. Keating's Redfern speech reverberated with positive energy and momentum towards Reconciliation and improving outcomes for Aboriginal people, beginning with truth-telling. Considering that speech was in 1992, we can deduce both that a lot has changed, and nothing has changed.

\section{References}

Aso.gov.au. (2015). Video Overview Keating Speech: The Redfern Address (1992) on ASO Australia's audio and visual heritage online. [online] Available at:

http://aso.gov.au/titles/spoken-word/keating-speech-redfern-address/.

Bailey, M. \& Brawley, 2. 2018, 'Why Weren't We Taught?: Exploring Frontier Conflict Through the Lens of Anzac', Journal of Australian Studies, 42 (1), pp. 19-33.

Daley, P. Enduring traditions of aboriginal protest: Truth-telling amid the dark shadows of history [online]. Griffith REVIEW, No. 60, 2018: [67]-81.

Dodson, M. 2017 “On Fixing the Constitution”, Saturday Paper, 7 October 2017.

HREOC, 1997. 'Bringing them home: The 'Stolen Children' report (1997) Human Rights and Equal Opportunity Commission.

McKenna, M., 2018, 'Moment of Truth: History and Australia's Future', Quarterly Essay, Issue 69.

Read, P. 2002, 'Clio or Janus? Historians and the Stolen Generations', Australian Historical Studies, vol. 33, no. 118, pp. 54-60.

Rutschmann, P. (2011). Vergangenheitsbewältigung: Historikerstreit and the Notion of Continued Responsibility. New German Review: A Journal of Germanic Studies, 25(1).

Lyndall, R., Richards, J., Pascoe, W., Debenham, J., Anders, R. J., Brown, M., Smith, R., Price, D. \& Newley, J. Colonial Frontier Massacres in Eastern Australia 1788 - 1872, v2.0 Newcastle: University of Newcastle, 2017, <http://hdl.handle.net/1959.13/1340762>.

Stanner, WEH, 1969, 'The Great Australian Silence' The 1968 Boyer Lectures: After The Dreaming, Sydney, ABC Enterprises, pp 18-29.

Taylor, C. 1997, 'The Politics of Recognition', in Multiculturalism and the Politics of Recognition: An Essay, Princeton University Press, pp, 25-73. 
Ungunmerr, M. To be listened to in her teaching: Dadirri: Inner Deep Listening and Quiet Still Awareness [online].EarthSong Journal: Perspectives in Ecology, Spirituality and Education, Vol. 3, No. 4, Autumn 2017: 14-15.

Yunupingu, G. 2016, 'ROM WATANGU: The Law of The Land', The Monthly, Issue 124, July, Melbourne, Schwartz Publishing Pty. Ltd. 